\title{
RESPONSE OF FABA BEAN CULTIVARS TO RHIZOBIUM INOCULATION, PHOSPHOROUS FERTILIZATION LEVELS ON YIELD AND YIELD ATTRIBUTES
}

\author{
A. Ali; A.G.*; Maha, M. Abdalla**; Bassiouny A.H.**and Essa, A.S.*** \\ * Dep. of Agro.; Fac. of Agric., Zagazig Univ., Egypt. \\ ** Dep. of Plant Prod. Fac. of Tech. and Development, Zagazig Univ. Egypt. \\ *** Essa, A.S. Agric. Eng. - Agric. Research Center, Dep. of Seed \\ Production - Ministry of Agriculture, Zagazig Egypt
}

\begin{abstract}
:
Two field trials were conducted at extension field on El-Nakaria Village, Zagazig district (Sharkia Governorate) during 2014/2015 and 2015/2016 to study the effect of Rhizobium treatment (treatment and untreatment) to phosphorous fertilizer levels $(0.0,15.5,31$ and $46.5 \mathrm{~kg}$ $\mathrm{P}_{2} \mathrm{O}_{5} / \mathrm{Fad}$ ) on three cultivars (Misr-3, Sakha-1 and Nubaria-2).
\end{abstract}

The results showed that rhizobium treatment was superior to untreatment in plant height $(\mathrm{cm})$, number of branches/plant, number of pods/plant, number of seeds/pod, seed index (gm), seed weight plant (gm), seed yield (ton/fad), straw yield (ton/fad) and biological yield (ton/fad). All studied characters were differ significantly, except, number of seeds/pod and biological yield in the first season and seed yield (ton/fad) in the second season. Increasing phosphorous levels from 0.0, 15.5, 31 and 46.5 $\mathrm{kg} \mathrm{P}_{2} \mathrm{O}_{5} / \mathrm{fad}$. increased significantly the studied characters. In general, adding $46.5 \mathrm{~kg} \mathrm{P}_{2} \mathrm{O}_{5} /$ fad. gave the highest values, followed by 31 and 15.5 $\mathrm{kg} \mathrm{P}_{2} \mathrm{O}_{5} / \mathrm{fad}$. While zero (without applied) was lower in this respect. Significant differences were found between three cultivars. Sakha-1 cv. was tallest in plant height (cm), and highest number of seeds/pod and straw yield (ton/fad). While, Nubaria-2 cv. was highest in number of pods/plant, seed weight plant (gm), seed yield (ton/fad) and biological yield ton/fad.. However, the three cultivars did not significantly affected in seed index $(\mathrm{gm})$ in both seasons and combined.

The results indicated that seed yield ton/fad showed significant and highly significantly correlation with studied characters. i.e. plant height (cm), number of seeds/pod, number of pods/plant and germination index.

Conclusively, all characters studied $R$-treated surpassed that untreated when all four $P$-levels. Also, nubaria $\mathrm{cv}$. gave the highest straw, seed and biological yields.

Key words: Faba bean cultivars, phosphorous, fertilization, yield and yield components, germination. 


\section{INTRODUCTION:}

According to the FAO report, world population will reach to about 9.8 billion in 2050 (FAO, 2010). Population growth, food shortages and high food prices have caused the increase in the population of hungry people in the world. So to feed the world's growing population, it is necessary to increase food production (Alipour et al., 2013). Faba bean (Vicia Faba L.) is an important feeding crop grown in winter season in Egypt. It's seed not only a cheep source of protein but also a food of high calorific and nutritive value especially in the diet of low income people. Egyptian Government is pressing hard to increase the yield and quality of faba bean plant through improving agricultural practices such as Rhizobium inoculation phosphorous fertilization and cultivars.

Many investigators had reported high variability on faba bean in yield and its attributes and quality (Khisravi and Ramezanpour, 2004; Alipour et al., 2013; Abdallah, 2014; Dubova et al., 2015, Hodua and Bouaziz 2016, Anteneh and Mnoelky 2017).

Phosphorous is major nutrient, especially for legumes. Many researchers showed positive effect of phosphorous fertilization on faba bean. Significant increases were achieved in faba bean yield and it's attributes by increasing phosphorous fertilization rate up to $30 \mathrm{~kg} \mathrm{P}_{2} \mathrm{O}_{5} / \mathrm{fad}$ (Khalil et al., 2004 and El-Saady et al., 2011) or $31 \mathrm{~kg} \mathrm{P}_{2} \mathrm{O}_{5} / \mathrm{fad}$; (Abbas et al., 2012).

Many investigators recorded significant differences between faba bean cultivars in yield and it's components. Maha and El-Wakil (2002) reported that the new cultivar Giza 714 produced highest plant height $(\mathrm{cm})$, number of pods/plant, dry weight of plant, biological yield (ton/fad) and straw yield (ton/fad). Amer et al., (2003) curtained the superiority of Sakha-1 faba bean cv. over Giza 461 one in seed yield. Talaat and Abdallah (2008) in Egypt, reported that Sakha-1 significantly surpassed Giza 40 in all previous tested parameters. Abbas et al., (2012). recorded that Sakha-1 produced the highest seed yield compared with Nubria-1 and Giza 843.

Therefore, the aim of the present study was to study the effect of Rhizobium inoculation and phosphorous fertilizer applications on three cultivars of faba bean.

\section{MATERIALS AND METHODS:}

Two field experiments were conducted at extension field in ElNakaria Village. Zagazig district (Sharkia Governorate) during the two successive seasons of $2014 / 2015$ and 2015/2016 to study the effect of 
Rhizobium inoculation and phosphorous fertilizer levels on three cultivars of faba bean.

The experiment included 24 treatments, which were the combinations of two Rhizobium treatments (treated and untreated), four levels of phosphorus (Zero, 15.5, 31.0 and $46.5 \mathrm{~kg} \mathrm{P}_{2} \mathrm{O}_{5} /$ fad) applied as calcium superphosphate fertilizer $\left(15.5 \% \mathrm{P}_{2} \mathrm{O}_{5}\right)$ in two equal doses 15 days after planting and before first irrigation on three cultivars faba bean (Misr3, Sakha-1 and Nubaria-2) during planting in the two growing seasons.

A split-split plot design with three replicates used with sub-sub plot area of $10.5 \mathrm{~m}^{2}$ having 6 ridges $3 \mathrm{~m}$ in length $0.60 \mathrm{~m}$ in width.

Faba bean seeds, previously inoculated before planting with the specific strains of Rhizobium leguminosarm, were sown on 15 November in the two successive seasons, respectively in hills, $20 \mathrm{~cm}$ apart, two seeds were inserted in hills. The two Rhizombium treatment were assigned to main plots, the sub-plots included four levels of phosphorus fertilizer and sub-sub plots for the three cultivars (Misr-3, Sakha-1 and Nubaria-2).

At harvest on 27 and 18 April in first and second growing seasons, respectively, ten guarded plants were randomly taken to determine the following yield attributes: plant height $(\mathrm{cm})$, number of branches/plant, number of pods/plant, number of seeds/pod, seed index (gm), seed weight plant (gm). In addition, the central two ridges of each plot were harvested to measure: seed yield (ton/fad.), straw yield ton/fad and biological yield (ton/fad.). Analysis of variance was performed according to SAS. (2008) system for windows. The interaction, capital letters were used to compare means in rows whereas, small ones were used to compare means in column of Duncan (1955). Further, the correlation coefficients among all possible combinations of characters were calculated using the method of Svab (1973).

\section{RESULTS AND DISCUSSION:}

\section{1- Effect Rhizobium treatments:}

The combined data in Table (1) show that Rhizobium treatment had the maximum values plant height, number of branches/plant and number of pods/ plant in both seasons and combined. It's recorded higher values of $100.50(\mathrm{~cm}) 4.00$ and 25.50 , respectively in the combined.

The data presented in Table (2) indicate the varietal differences in the average number of seeds/pod, seed index (gm) and seed weight plant (gm). It is clear that Rhizobium treatment produced higher number of pod/plant, 


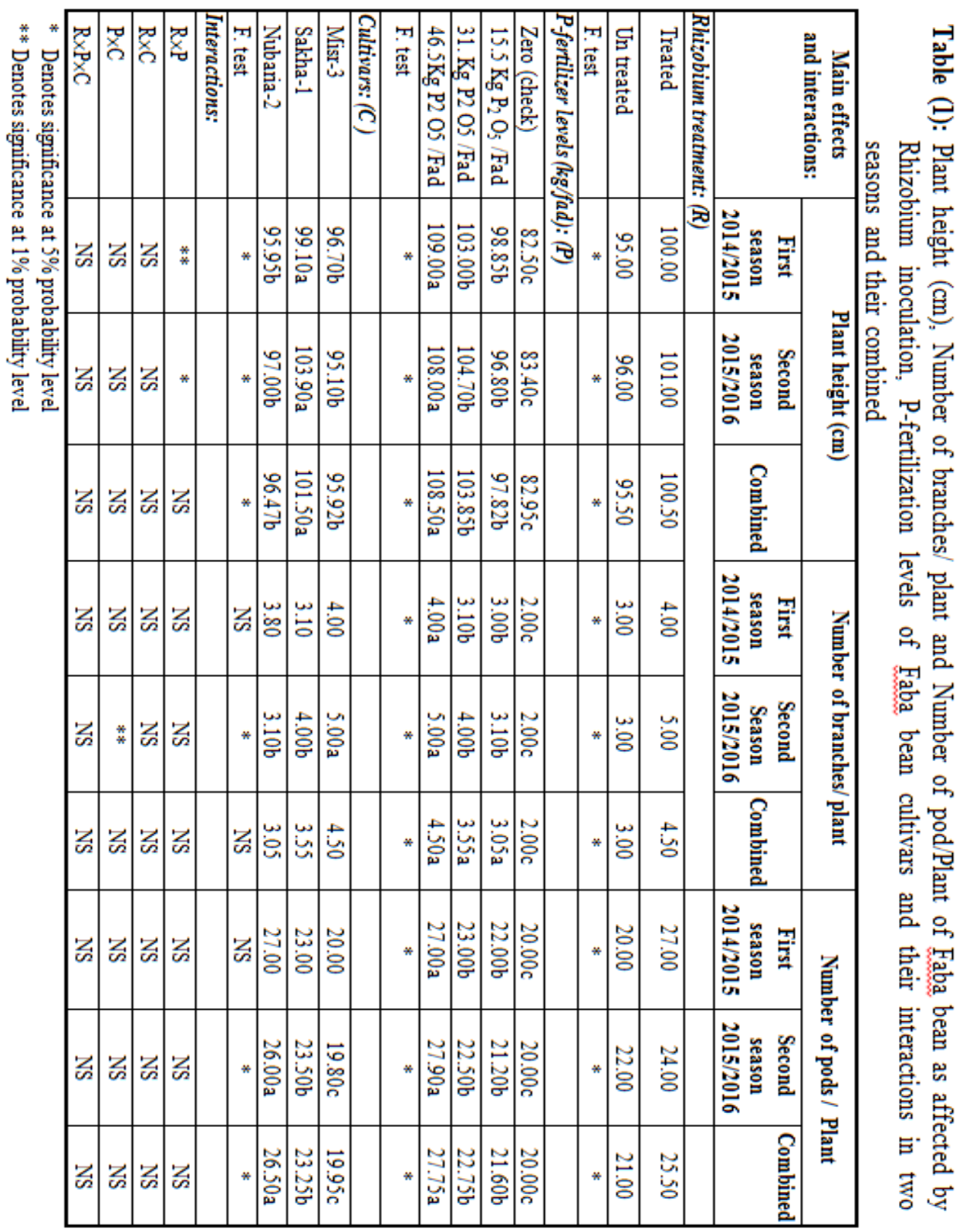




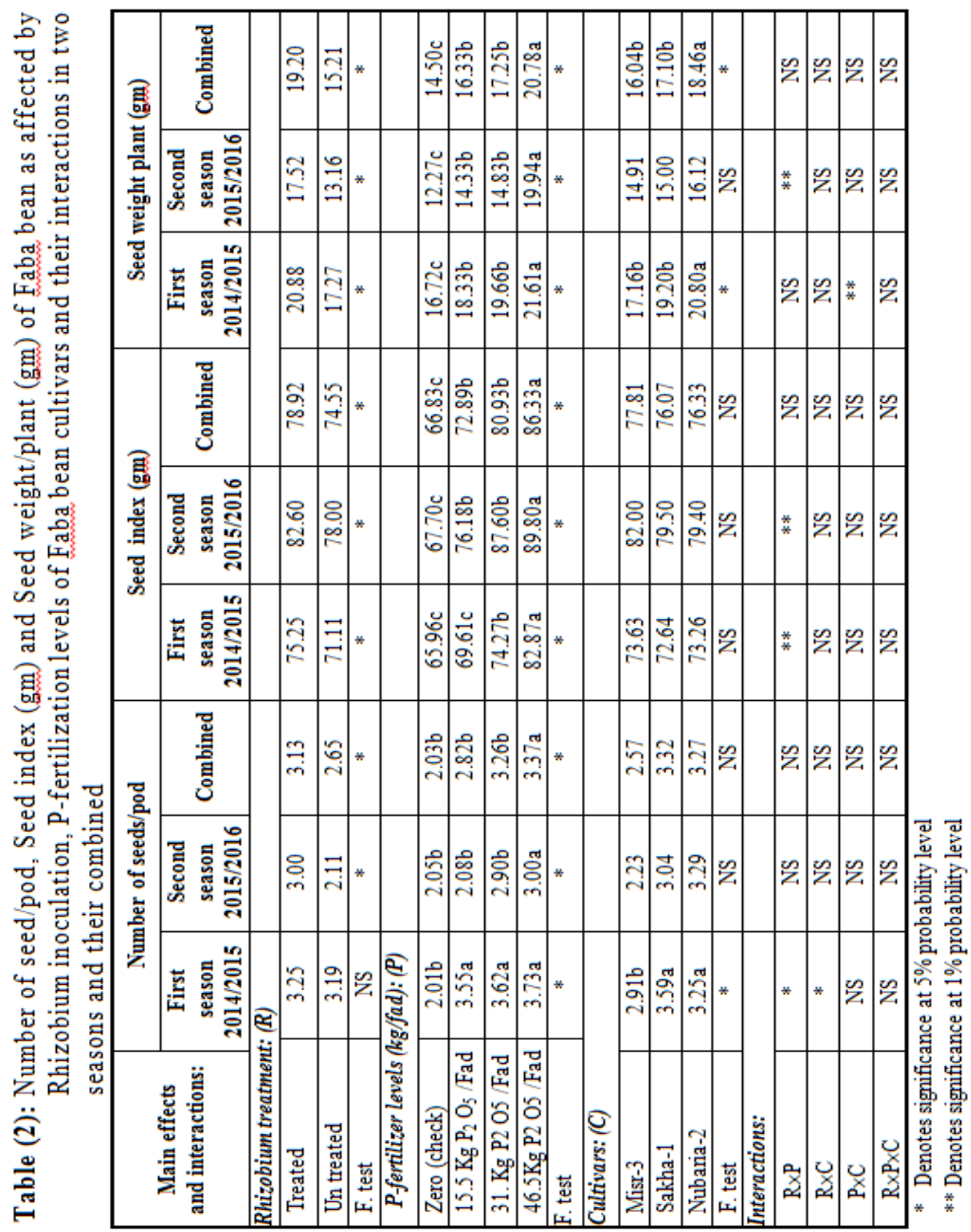


heavier seed index (gm) and seed weight/plant (gm) during both seasons and their combined compared with plant untreated with respect by Rhizobium. While no significant differences was observed during the first season of respect number of seeds/pod.

Data recorded in Table (3) show that over the two seasons, there were highly significant and significant differences between Rhizobium treatment in seed yield (ton/fad), straw yield (ton/fad.) and biological yield ton/fad. in the combined. These results are in agreement with those reported by Hessian (2000); Khisavi and Ramezanpour (2004); Alipour et al., (2013) and Abdallah (2014).

\section{2- Effect of phosphorous fertilization:}

Two seasons and combined analysis data presented in Tables (1, 2 and 3) show that increasing level of phosphorous fertilization levels from zero to $46.5 \mathrm{~kg} \mathrm{P}_{2} \mathrm{O}_{5} / \mathrm{fad}$. had positive and significant effects on all studied yield determinations.

Increasing P-levels from zero to $46.5 \mathrm{~kg} \mathrm{P}_{2} \mathrm{O}_{5} / \mathrm{fad}$. gradually increased seed yield (ton/fad.) and such increments reached around 7.45, 15.74 and $22.92 \%$ when P-level increased from 0.0 to $15.5,31.0$ to $46.5 \mathrm{~kg}$ $\mathrm{P}_{2} \mathrm{O}_{5} / \mathrm{fad} /$ respectively. Such results indicated the important rule of phosphorous in improving the productivity of faba bean crop.

Likewise, increasing P-levels increased straw and biological yields (ton/fad.) by 27.92 and $22.92 \%$ when P-level increased from 0.0 to $46.5 \mathrm{~kg}$ $\mathrm{P}_{2} \mathrm{O}_{5} /$ fad. for straw and biological yields (ton/fad.) as in the combined data. These results are agreement with those reported by Maha and ElWakil (2002); Abdalla (2002); Nawar and Mousa (2002); Khalil et al., (2004); Abd-Elaziz, El-Set (2005); Attia (2009); Ibrahim (2009); El-Saady et al., (2011); Abbas, et al., (2012) and Abou-Amer et al., (2014), who's found that faba bean seed yield and it's attributes were significantly increased with increasing the rate of phosphorous fertilization. In this connection, Halimak and Barber (1984) reported that adding P-fertilizer significantly increased root surface area and this was important in supplying the nutrient need by plants. It is well established also that phosphorous is an essential and principal element in energy compounds.

\section{3- Cultivar Variation:}

The combined data in Tables (1, 2 and 3) show that Sakha-1 cv. had the maximum values of taller plants height, number of seeds/pods and straw yield "ton/fad". Sakha-1 recorded higher values of plant height $101.50(\mathrm{~cm})$, number of seeds/pods 3.32 and straw yield (ton/fad.) 1.392 in combined, respectively. 


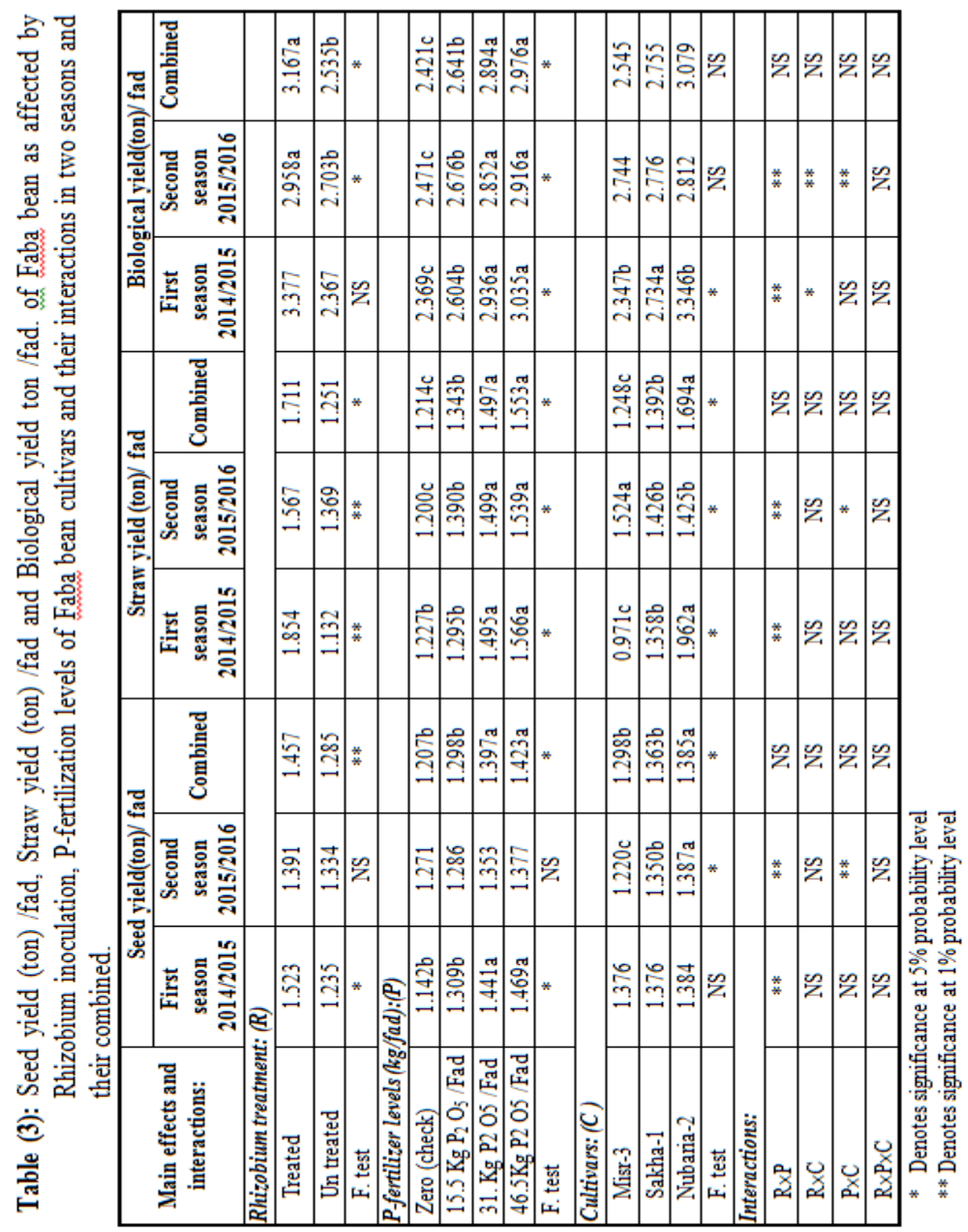


The data presented in Tables (1,2 and 3) show that Nubaria-2 cv. had higher number of pods/plant, seed weight/plant (gm), seed yield (ton/fad.) and biological yield (ton/fad.). Nubaria-2 recorded higher and heavier plants during both seasons and their combined compared with Misr-3 and Sakha-1. The three cultivars did not significantly differ in seed index (gm) during both seasons and the combined. These results are in agreement with those reported by Metwally et al., (2000); Saad and El-Kholoy (2000); Awaad (2002); Maha and El-Wakil (2002); Abd El-Hakim (2003); El-Galfy (2005); Talaat and Abdallah (2008); El-Sayed (2010) and Abbas et al., (2012).

\section{4- Effect of Interaction}

a) Rhizobium X P-levels:

Interaction effects of Rhizobium treat X P-levels on some yield attributes and yields in the second season are shown in Table 4. Plant height $(\mathrm{cm})$, seed

Table (4): Effect of Rhizobium inoculation X Phosphour levels interaction on some yield attributes and biological yield in second season.

\begin{tabular}{|c|c|c|c|c|}
\hline P-levels & Zero & $15.5 \mathrm{~kg} \mathrm{P}_{2} \mathrm{O}_{5}$ fad & $31 \mathrm{~kg} \mathrm{P}_{2} \mathrm{O}_{5} / \mathrm{fad}$ & $46.5 \mathrm{~kg} \mathrm{P}_{2} \mathrm{O}_{5} /$ fad \\
\hline $\begin{array}{l}\text { Rhizobium } \\
\text { treatment }\end{array}$ & \multicolumn{4}{|c|}{ Plant height (cm) } \\
\hline Treated & $\begin{array}{c}\mathrm{D} \\
83.99\end{array}$ & $\begin{array}{c}\mathrm{C} \\
85.55\end{array}$ & $\begin{array}{c}\mathrm{B} \\
93.22\end{array}$ & $\begin{array}{c}\mathrm{A} \\
103.00\end{array}$ \\
\hline \multirow[t]{2}{*}{ Un Treated } & $\begin{array}{c}\mathrm{D} \\
80.92\end{array}$ & $\begin{array}{c}\mathrm{C} \\
82.55\end{array}$ & $\begin{array}{c}\mathrm{B} \\
89.88\end{array}$ & $\begin{array}{c}\mathrm{A} \\
99.77\end{array}$ \\
\hline & \multicolumn{4}{|c|}{ Seed index $(\mathrm{gm})$} \\
\hline Treated & $\begin{array}{c}\mathrm{C} \\
72.00\end{array}$ & $\begin{array}{c}\text { B } \\
75.39 \\
\end{array}$ & $\begin{array}{c}\text { BC } \\
73.00\end{array}$ & $\begin{array}{c}\text { A } \\
80.43 \\
\end{array}$ \\
\hline \multirow[t]{2}{*}{ Un Treated } & $\begin{array}{c}\mathrm{B} \\
71.50\end{array}$ & $\begin{array}{c}\text { A } \\
73.97\end{array}$ & $\begin{array}{c}\text { A } \\
74.99\end{array}$ & $\begin{array}{c}\text { A } \\
75.77\end{array}$ \\
\hline & \multicolumn{4}{|c|}{ Seed weight/plant (gm) } \\
\hline Treated & $\begin{array}{c}\mathrm{D} \\
12.50\end{array}$ & $\begin{array}{c}\mathrm{C} \\
14.20\end{array}$ & $\begin{array}{c}\mathrm{B} \\
15.60\end{array}$ & $\begin{array}{c}\mathrm{A} \\
17.50\end{array}$ \\
\hline \multirow[t]{2}{*}{ Un Treated } & $\begin{array}{c}\mathrm{C} \\
11.00\end{array}$ & $\begin{array}{c}\mathrm{B} \\
12.90\end{array}$ & $\begin{array}{c}\mathrm{AB} \\
12.99 \\
\end{array}$ & $\begin{array}{c}\mathrm{A} \\
13.10 \\
\end{array}$ \\
\hline & \multicolumn{4}{|c|}{ Seed yield (ton/fad) } \\
\hline Treated & $\begin{array}{c}\mathrm{B} \\
1.350\end{array}$ & $\begin{array}{c}\mathrm{B} \\
1.353\end{array}$ & $\begin{array}{c}\mathrm{A} \\
1.387\end{array}$ & $\begin{array}{c}\mathrm{A} \\
1.385\end{array}$ \\
\hline Un Treated & $\begin{array}{c}\mathrm{B} \\
1.280 \\
\end{array}$ & $\begin{array}{c}\mathrm{B} \\
1.286 \\
\end{array}$ & $\begin{array}{c}\mathrm{B} \\
1.235 \\
\end{array}$ & $\begin{array}{c}\mathrm{A} \\
1.343 \\
\end{array}$ \\
\hline & \multicolumn{4}{|c|}{ Straw yield (ton/fad) } \\
\hline Treated & $\begin{array}{c}\mathrm{C} \\
0.962\end{array}$ & $\begin{array}{c}\mathrm{B} \\
1.190\end{array}$ & $\begin{array}{c}\mathrm{A} \\
1.359\end{array}$ & $\begin{array}{c}\mathrm{A} \\
1.439\end{array}$ \\
\hline Un Treated & $\begin{array}{c}\mathrm{C} \\
0.934 \\
\end{array}$ & $\begin{array}{c}\mathrm{C} \\
1.027 \\
\end{array}$ & $\begin{array}{c}\mathrm{B} \\
1.132 \\
\end{array}$ & $\begin{array}{c}\mathrm{A} \\
1.360 \\
\end{array}$ \\
\hline & \multicolumn{4}{|c|}{ Biological Yield (ton/fad) } \\
\hline Treated & $\begin{array}{c}\mathrm{C} \\
2.232\end{array}$ & $\begin{array}{c}\mathrm{B} \\
2.338\end{array}$ & $\begin{array}{c}\mathrm{B} \\
2.346\end{array}$ & $\begin{array}{c}\mathrm{A} \\
2.817\end{array}$ \\
\hline Un Treated & $\begin{array}{c}\mathrm{B} \\
2.205\end{array}$ & $\begin{array}{c}\mathrm{A} \\
2.817\end{array}$ & $\begin{array}{c}\mathrm{B} \\
2.322 \\
\end{array}$ & $\begin{array}{c}\mathrm{A} \\
2.657 \\
\end{array}$ \\
\hline
\end{tabular}


index, seed weight/plant (gm), seed yield (ton/fad.) straw yield (ton/fad.) and biological yield (ton/fad.) responded to the highest from zero of P-fertilizer (46.5 $\mathrm{kgP}_{2} \mathrm{O}_{5} / \mathrm{fad}$.) where as untreated plants showed gradually response to $46.5 \mathrm{kgP}_{2} \mathrm{O}_{5} / \mathrm{fad}$. On the other hand of all characters studied of R-treatment surpassed that un-treatment with all four P-levels.

\section{b) P-levels $X$ Cultivars:}

Interaction effects of P-levels X Cultivars on seed, straw and biological yields (ton/fad.) were significant and shown in Table (5). All characters responded significantly to the highest P-level $46.5 \mathrm{~kg} \mathrm{P}_{2} \mathrm{O}_{5} /$ fed. irrespective to cultivars Sakha-1 which surpassed the two cultivars Misr-3 and Nubaria-2 in seed, straw and bidogical yields "ton/fad." 1.469, 1.540 and 2.817 (ton/fad.), respectively.

Table (5): Effect of phosphorours levels X Cultivars interactions on seed, straw and biological yields (ton/fad.) in the second season.

\begin{tabular}{|c|c|c|c|c|}
\hline & Zero & $15.5 \mathrm{~kg} \mathrm{P}_{2} \mathrm{O}_{5}$ fad & $31 \mathrm{~kg} \mathrm{P}_{2} \mathrm{O}_{5} / \mathrm{fad}$ & $46.5 \mathrm{~kg} \mathrm{P}_{2} \mathrm{O}_{5} / \mathrm{fad}$ \\
\hline Cultivars & \multicolumn{4}{|c|}{ Seed yield ton/fad } \\
\hline Misr-3 & $\begin{array}{c}\mathrm{D} \\
1.240 \mathrm{a}\end{array}$ & $\begin{array}{c}\mathrm{B} \\
1.309\end{array}$ & $\begin{array}{c}\mathrm{A} \\
1.441 \mathrm{a}\end{array}$ & $\begin{array}{c}\mathrm{C} \\
1.286 \mathrm{~b}\end{array}$ \\
\hline Sakha-1 & $\begin{array}{c}\mathrm{C} \\
1.271 \mathrm{a}\end{array}$ & $\begin{array}{c}\mathrm{B} \\
1.377 \mathrm{a}\end{array}$ & $\begin{array}{c}\mathrm{B} \\
1.353 \mathrm{~b}\end{array}$ & $\begin{array}{c}\mathrm{A} \\
1.469 \mathrm{a}\end{array}$ \\
\hline Nubaria-2 & $\begin{array}{c}\mathrm{C} \\
1.209 \mathrm{a}\end{array}$ & $\begin{array}{c}\mathrm{B} \\
1.343 \mathrm{a}\end{array}$ & $\begin{array}{c}\mathrm{B} \\
1.343 \mathrm{a}\end{array}$ & $\begin{array}{c}\mathrm{B} \\
1.377 \mathrm{a}\end{array}$ \\
\hline & \multicolumn{4}{|c|}{ Straw Yield (ton/fad) } \\
\hline Misr-3 & $\begin{array}{c}\mathrm{B} \\
0.961 \mathrm{~b}\end{array}$ & $\begin{array}{c}\mathrm{B} \\
1.132 \mathrm{~b}\end{array}$ & $\begin{array}{c}\mathrm{A} \\
1.359 \mathrm{~b}\end{array}$ & $\begin{array}{c}\mathrm{A} \\
1.466 \mathrm{a}\end{array}$ \\
\hline Sakha-1 & $\begin{array}{c}\mathrm{B} \\
1.356 \mathrm{a} \\
\end{array}$ & $\begin{array}{c}\mathrm{C} \\
1.027 \mathrm{c}\end{array}$ & $\begin{array}{c}\mathrm{B} \\
1.358 \mathrm{~b} \\
\end{array}$ & $\begin{array}{c}\mathrm{A} \\
1.540 \mathrm{a} \\
\end{array}$ \\
\hline Nubaria-2 & $\begin{array}{c}\mathrm{C} \\
0.962 \mathrm{~b}\end{array}$ & $\begin{array}{c}\mathrm{B} \\
1.360 \mathrm{a}\end{array}$ & $\begin{array}{c}\mathrm{A} \\
1.439 \mathrm{a}\end{array}$ & $\begin{array}{c}\mathrm{A} \\
1.426 \mathrm{a}\end{array}$ \\
\hline & \multicolumn{4}{|c|}{ Biological Yield (ton/fad) } \\
\hline Misr-3 & $\begin{array}{c}\mathrm{A} \\
2.80 \mathrm{a}\end{array}$ & $\begin{array}{c}\mathrm{C} \\
2.462 \mathrm{a}\end{array}$ & $\begin{array}{c}\mathrm{B} \\
2.653 \mathrm{a}\end{array}$ & $\begin{array}{c}\mathrm{A} \\
2.755 \mathrm{a}\end{array}$ \\
\hline Sakha-1 & $\begin{array}{c}\mathrm{C} \\
2.235 \mathrm{~b} \\
\end{array}$ & $\begin{array}{c}\mathrm{C} \\
2.337 \mathrm{~b} \\
\end{array}$ & $\begin{array}{c}\mathrm{B} \\
2.699 \mathrm{a} \\
\end{array}$ & $\begin{array}{c}\mathrm{A} \\
2.817 \mathrm{a} \\
\end{array}$ \\
\hline Nubaria-2 & $\begin{array}{c}\mathrm{D} \\
2.262 \mathrm{~b}\end{array}$ & $\begin{array}{c}\mathrm{C} \\
2.460 \mathrm{a} \\
\end{array}$ & $\begin{array}{c}\mathrm{B} \\
2.579 \mathrm{a}\end{array}$ & $\begin{array}{c}\mathrm{A} \\
2.726 \mathrm{a} \\
\end{array}$ \\
\hline
\end{tabular}

\section{Correlation coefficients:}

The interrelationship among seed yield and its attributes of faba bean as simple correlation are shown in Table 6. 


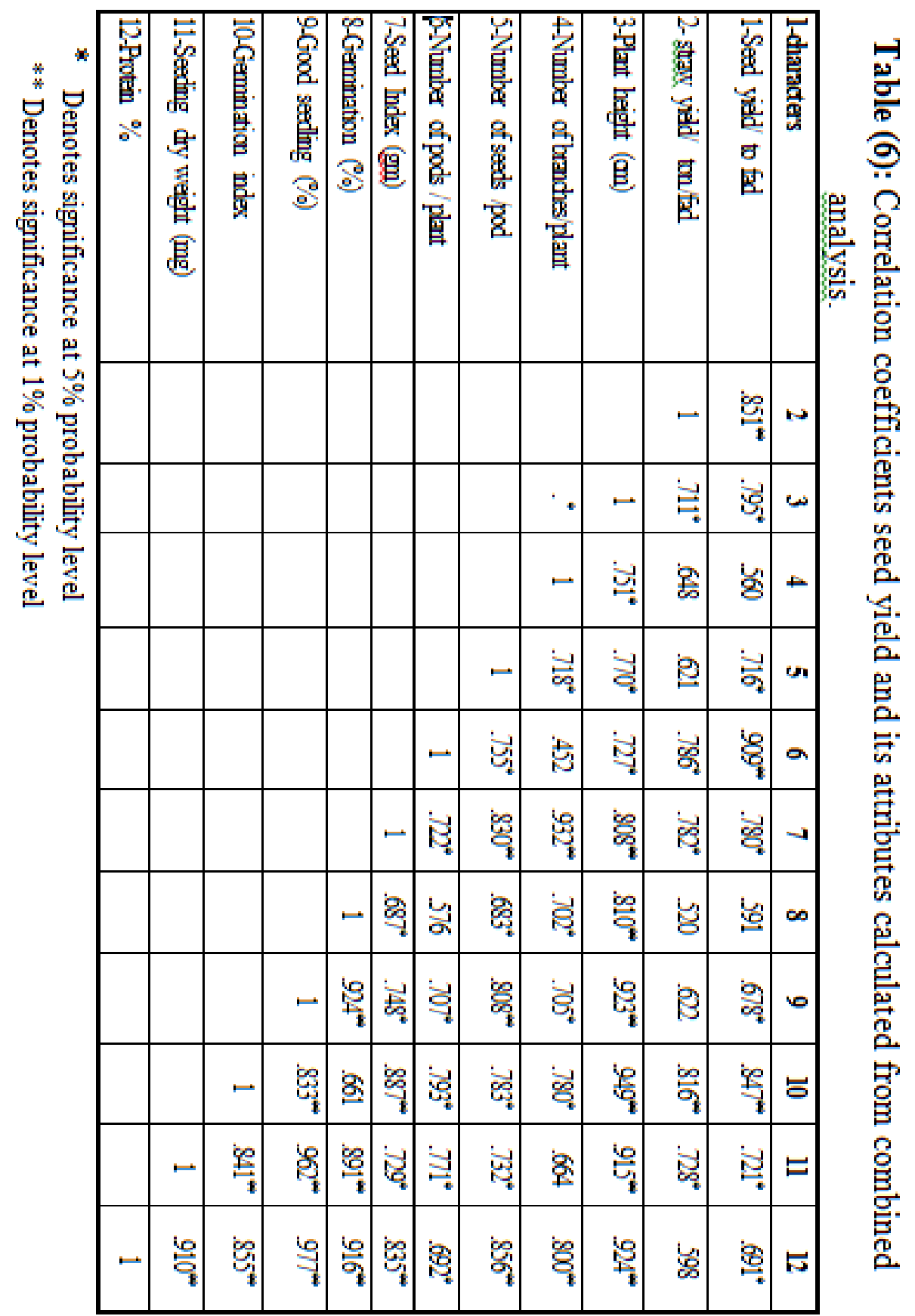


Seed yield was positively and highly significant correlacted with all characters studied i.e. straw yields $\left(\mathrm{r}=0.851^{* *}\right)$, plant height $\left(\mathrm{r}=0.795^{*}\right)$, number of seeds/pod $\left(\mathrm{r}=0.716^{*}\right)$, number of pods/plant $\left(\mathrm{r}=0.909^{* *}\right)$, germination $\%(\mathrm{r}=0.591)$, good seedling $\%(\mathrm{r}=0.679 *)$, germination index $\left(\mathrm{r}=0.847^{* *}\right)$, seedling dry weight $(\mathrm{mg})\left(\mathrm{r}=0.721^{*}\right)$ and protein\% $(\mathrm{r}=$ $0.691 *)$.

These results are in accordance with those reported by Maha and ElWakil (2002); Fatma and Mehasen (2006) and Alipour et al., (2013).

Conclusively, all characters studied R- treated surpassed that untreated when all four P- levels. Also, nubaria $2 \mathrm{cv}$. gave the highest straw, seed and biological yields.

\section{REFERENCES}

Abbas, E.E, M.M. El-Metwally and M.R.A. Mohamed (2012): Respone of some Faba bean cultivars to Different levels of phosphorous Fertilizer with inoculation by Phosphorous Solubilizing fungi J. plant Production, Mansoura Uni., Vol. 3 (9): 2479-2494.

Abd El-Hakim, K.M. (2003): Effect of planting date and plant density on growth and yield of some faba varieties M. Sc. Thesis, Fac. of Agric. Cairo Univ.

Abdalla, A.M. (2002): Effect of bio-and mineral phosphours fertilizer on growth, productivity and nutritional value of faba bean. Egypt. J. of Horticulture 29 (2): 187-203.

Abdallah, Amany (2014): Response of faba bean (Vicia faba L.) to planting densities and bio-meneral fertilization system. AmericaEurasian J. Agric, Environ Sci. 14 (6): 541-545.

Abd-Elaziz, El-Set, A. (2005): Effect of phosphor in with different levels of phosphouras ferilizers an faba bean under calcareous soil conditions Minufiya J. Agric. Res., 30(20): 549-563.

Abou-Amer, A.I., Hassan A. Fawy and Abdel wahab, M.A.S.(2014): Of mineral fertilization and plant density on faba bean (vicia faba) production in siwa onsis. Res. Soil. Water and environ. Res. Inst., ARC. Ciza. Egypt. 19-26.

Alipour, N. G. A. Z. Fakharian and K. M. Mohammad (2013): Evaluating the effects of different planting densities and in culation with Rhizobium bacteria on morphological characteristics and yield of faba bean (CV. Barakat) Inter. Jou. of Biosc. (IJB). ISSN: 2206655(print) 2222-5234 (on line Vol.3, No. 7, P. 42-48, 
Amer, M.Z.; Hassan A.H.; Hussein, M.M. Redi, Ola A.M. El-Galaly, M.M. El-Hady and N.M. Abou-Zeid (2003): Sakha-2, A New released foliar disease resistant faba bean (Vicia faba L.) cultivar. J. Agric Sci. Mansoura Univ., 28 (2) 785-790.

Anteneh A.G. and Mnoelky (2017): Symbiotic effectiveness of Rhizobium leguminosarm bv. Vixieae isolated from major highland puleses on field pea (pisumsatirum L.) insoil 15.410-419.

Attia, T. S. M. (2009): Effect of some agronomic practices of productivity of faba bean under sandy soil condition. Ph. D. Thesis, Fac. Of Agric., Zagazig Univ., Egypt.

Awaad, H.A. (2002): Phenotypic and genotypic stability of some faba bean (Vicia faba L.) varieties. Epypt. J. plant Breed. 6(1): 1-15.

Dubova L.; A. Senberga and I. Alsing (2015): The effect of double, Inocvla. Ation on the Broad Beans (Voivia fava L.) yield quality volme.

Duncan, B.D. (1955): Multiple range and Multiple f. test Biometrics 11:152.

El-Galfy ,. A.M.K. (2005): Effect of some irrigation treatments on yield, yield components and seed quality characteristics of some faba bean (Vicia faba L.) varieties. Annals-of-Agricultural-Science-Moshtohor. 43(1):51-62.

El-Saady, A. S. M.; Gh. Sh. El-Atawy and R. H Atia (2011): Effect of furrow Spacing and Phophorus fertilization treatments on faba bean yield, nutrients content and some water relationships. J. Soil Sci. Agric. Eng., Mansoura univ., Vol.2 (5): 597-610.

El-Sayed (2010): Effect of some agronomic treatments on yield and quality of faba bean (Vicia faba L.) under Sharkia Governorate's condition. Ph.D. Thesis, Fac. Of Agric., Zagazig Univ., Egypt.

FAO (2010): Food and Agriculture Organization of the united Nation Quarterly Bulleten of statistic, Rom, Italy.

Fatma A.M. and Mehasen (2006): Response of two new genotypes of faba bean to nitrogen and phosphorous fertilization Annals of Agric Sc., Moshtohor, 877-886.

Halimak, W. B. and S. A. Barber (1984): Root growth and morphology, nutrient uptake and nutrient status early growth of soybean as affected by soil P and K, Agronomy. J. 76:209.

Hussein, A.M.I. (2000): Evaluation of some mung bean varieties under certain agricultural treatments. M. Sc Thesis, Fac. Of Agric., Ain Shams Univ., Egypt. 
Houda S.I. and Bouaziz (2016): Effect of rhizobia inoculation on nodulation and plant growth of faba bean in Tunisian farmer's field test Vol. 4 (10), pp. 227-234.

http://dx.doi.org/10.12692/ijb/3.7.42-48.

Ibrahim, M. M. (2009): Effect of plant spacing and phosphorous fertilization on growth and productivity of faba bean. J. Agric. Sci. Mansoura Univ., 34 (2) : 1183-1196.

Khalil, F.A.,; K.A.A. El-Shaikh and R.E. El-Lithy (2004): Response of two faba bean cultivars to different levels of phosphorous and sulphur applications. Assiut J. Agric. Sci., 35(2):289-309.

Khisravi H. and Ramezanpur M.R. (2004): Exploring the effects of some growh of faba bean in Mazandaran. Journal of soil and water sciences 18(2), 146-152.

Maha M. and El-Wakil (2002): Response of two faba bean (Vicia faba, L.) cultivars to potassium and phosphorous fertilization. (7)2 p.p. 245258.

Metwally, A.A.; M.M. Shafik, M.A. Hassanin and D.S Darwish (2000): Influence of soing dates and population densities on performance of some Faba bean varieties grown in newly reclaimed land .J. Agric. Sci. Mansoura Univ., 25 (9): 5587-5599.

Nawar, F.R.R. and A.I.M. Moussa (2002): Effect of tillage method, plant spacing and phosphours fertilization on faba bean productivity in reclaimed land. Egypt. J. Appl. Sci., 17(1): 105-115.

Saad,. A.O.M. and M. A. El-Kholy (2000): Response of some faba bean cultivars to phosphorous and magnesium fertilization. EgyptianJournal-of-Agronomy. 22:19-38.

SAS institute (2008): SAS user guides version 9.2. SAS institute Inc. cary, North USA, Carolina.

Svab, J. (1973): Biometriai Medszerek a Kutatasban - Mezogazdasagi kiado, Budapest.

Talaat,. N. B and A. M. Abdallah (2008): Response of faba bean (Vicia faba L.) to dual inoculation with Rhizobium and VA Mycorrhiza under different levels of $\mathrm{N}$ and $\mathrm{P}$ fertilization. Journal of Applied Science Research. (September): 1092-1102. 


\section{استجابة بعض أصناف الفول البلاي للريزوبيوم والتسميد الفوسفاتي علي

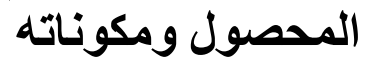
أحمد عبد الغتي علي* - ـ مها محمد عبد الله*** ـ ـ أمين هاشم بسيوني** -

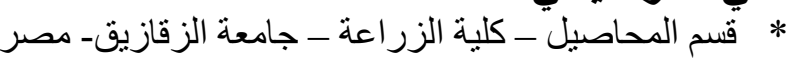

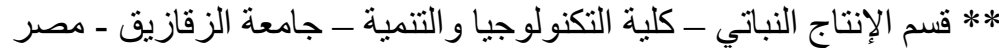

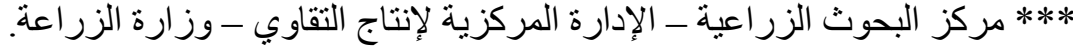

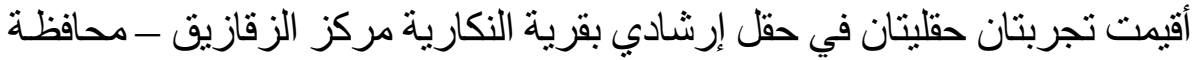

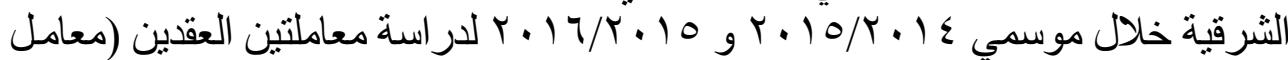

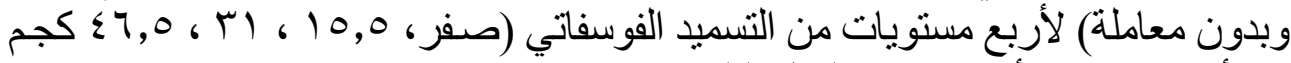

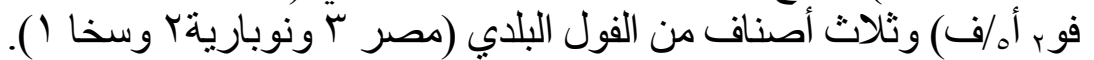

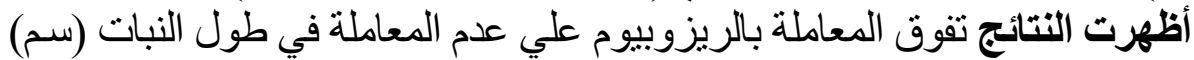

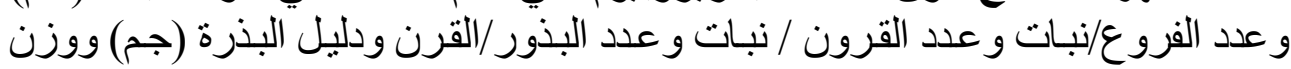
بذور النبات (جم) ومحصول البذرة والقش و البيولوجي (طن/ف) وعند).

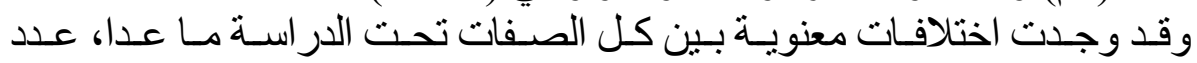

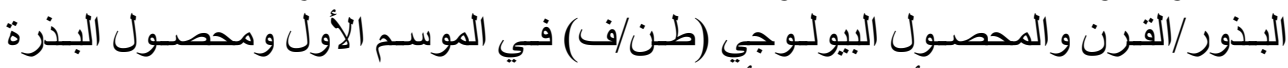

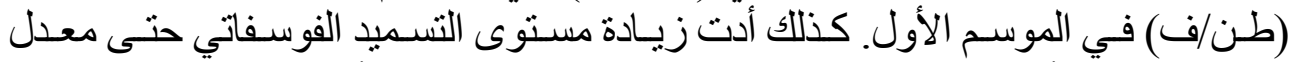

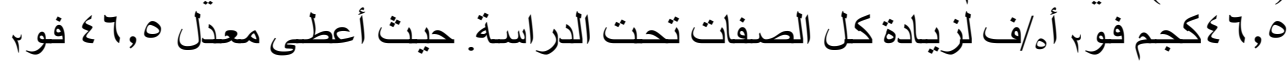

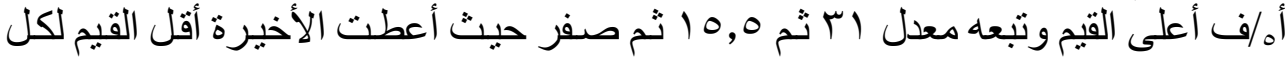

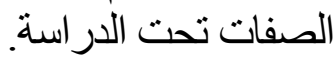

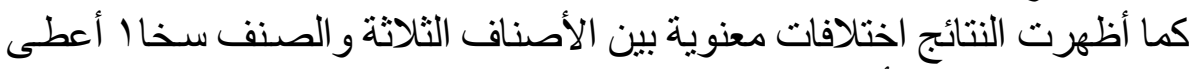

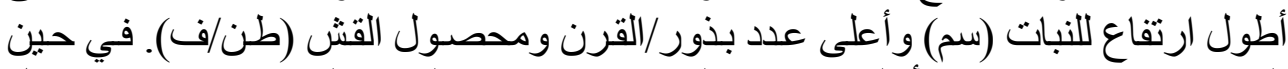

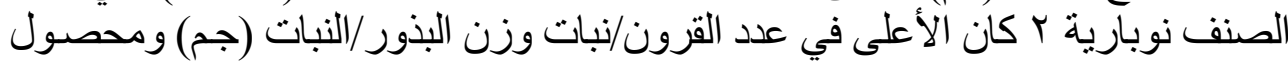

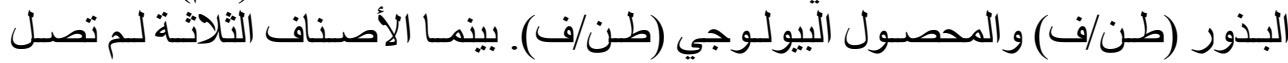
لمستوى المعنوية في دليل البذرة (جم) لموسمي الزر اعة المئ.

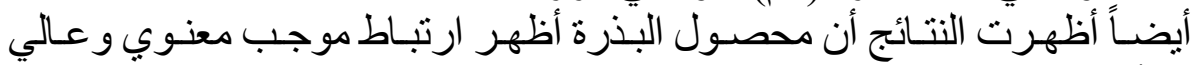

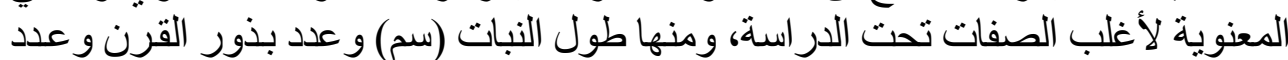
قرون النبات ودليل الإنبات.

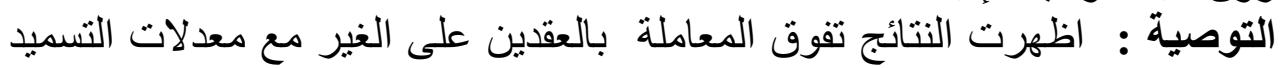

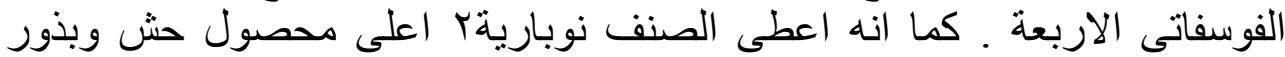
وبيولوجى (طن / ف). 